\author{
Loyalitas Kreativitas \\ Aldi Masyarakat Kreatif
}

P-ISSN 2722-2101, E-ISSN 2722-4201

Program Studi Ekonomi Manajemen Universitas Pamulang

Jurnal LOKABMAS Kreatif Vol.02,No.01,Maret 2021 Hal. 36-47

Email:jurnalkreatif.manajemen@gmail.com

\title{
PELATIHAN PEMBUATAN MASKER NON MEDIS MANUAL SERTA SOSIALISASI MANAJEMEN PEMASARAN PADA ERA NEW NORMAL DI RUMAH PINTAR TANGERANG RAYA
}

\author{
Indri Kharisma ${ }^{1}$, Ardi Bachtiar ${ }^{2}$, Ananda Hadistia ${ }^{3}$, \\ Shela Indah Savitri ${ }^{4}$, Indra Januar Rukmana ${ }^{5}$ \\ Dosen Manajemen Fakultas Ekonomi Universitas Pamulang \\ Email: dosen02474@unpam.ac.id, dosen02475@unpam.ac.id, dosen02397@unpam.ac.id, \\ dosen02583@unpam.ac.id, dosen02585@unpam.ac.id
}

\begin{abstract}
The purpose of this Community Service activity is to carry out one of the Tri Dharma of Higher Education. In addition, this is to improve the skills of mothers or guardians of students at Rumah Pintar Tangerang Raya in making handicrafts such as making non-medical masks manually and also adding to marketing strategies in the business that was carried out during the Covid-19 Pandemic with the aim of increasing the household economy. The method of implementing Community Service activities used is counseling, practicum, and also brainstorming. The technique in implementing Community Service activities used is group work with 10 (ten) participants, mothers or guardians of students at Rumah Pintar Tangerang Raya (RPTR). As for the output of this Community Service activity in the form of publication in the media online and one scientific article published through the PKM PKM Lokabmas Journal of Pamulang University, as well as increasing the knowledge, understanding, and skills of the mothers or guardians of students at the Tangerang Raya Smart House (RPTR) in training on making manual non-medical masks and disseminating marketing management at the new normal Covid-19 pandemic era.
\end{abstract}

Keywords: Masks, non-medical, marketing management, covid-19

\begin{abstract}
Abstrak
Tujuan dari kegiatan Pengabdian Kepada Masyarakat ini adalah untuk melaksanakan salah satu Tri Dharma Perguruan Tinggi. Selain itu adalah untuk meningkatkan keterampilan para ibu atau wali murid di Rumah Pintar Tangerang Raya dalam membuat kerajinan tangan seperti pembuatan masker non medis secara manual dan juga menambah strategi pemasaran dalam usaha yang dijalankannya di masa Pandemi Covid-19 dengan tujuan dapat meningkatkan perekonomian Rumah Tangga. Metode pelaksanaan kegiatan Pengabdian Kepada Masyarakat yang digunakan adalah penyuluhan, praktikum, dan juga curah pendapat. Teknik dalam pelaksanaan kegiatan Pengabdian Kepada masyarakat yang digunakan adalah kerja kelompok denhgan jumlah peserta 10 (sepuluh) orang ibuibu atau wali murid dari peserta didik di Rumah Pintar Tangerang Raya(RPTR).Adapun luaran dari kegiatan Pengabdian kepada Masyarakat ini berupa publikasi pada media online dan satu artikel ilmiah yang dipublikasikan melalui Jurnal Lokabmas Kreativ PKM Universitas Pamulang, serta peningkatan pengetahuan, pemahaman, dan keterampilan para ibu atau wali murid peserta didik di Rumah Pintar Tangerang Raya (RPTR) dalam pelatihan pembuatan masker non medis manual serta sosialisasi manajemen pemasaran pada era new normal pandemic covid-19.
\end{abstract}

Kata kunci : Masker, non-medis, manjemen pemasaran, covid-19 


\section{PENDAHULUAN}

\subsection{Analisis Situasi Permasalahan}

Indonesia masuk kedalam Negara yang terjangkit Covid-19 saat diumumkannya (Senin, 02 Maret 2020) bahwa ada 2 Warga Negara Indonesia (WNI) yang terjangkit virus tersebut tepatnya di daerah Depok. Untuk menekan lonjakan kenaikan penyebaran Covid-19 maka Pemerintah dan Kementrian Kesehatan menerbitkan protocol penanganan Virus Corona yaitu dengan menggunakan masker, rajin mencuci tangan menggunakan sabun dan juga menjaga jarak, dan pastinya juga setiap orang harus tetap menjaga imunitas tubuhnya agar tetap fit. Saat ini menggunakan masker merupakan suatu kewajiban yang sudah dibuat perundangundangannya oleh pemerintah, bahkan pemerintah sudah menerapkan system tilang bagi masyarakat yang berpergian tanpa menggunakan masker, dari sinilah kami melihat peluang bahwa memproduksi masker merupakan suatu peluang usaha yang sangat menjanjikan saat ini, ditambah lagi dampak dari Covid-19 ini sangat terasa dalam sektor perekonomian masyarakat umumnya, banyak karyawan yang dirumahkan, usaha mikro dan makro mengalami penurunan income.

Dari hasil pengamatan dan survei lokasi di Rumah Pintar Tangerang Raya yang beralamat di Komplek Griya Asri Pamulang Blok E9 N0.7, Kelurahan Bakti Jaya, Kecamatan Setu, Kota Tangerang Selatan. Dalam menjalankan kegiatannya para ibu atau wali murid peserta didik Rumah Pintar Tangerang Raya dalam mengasah keterampilan guna memperoleh penghasilan tambahan dalam menghadapi pandemic Covid- 19.

Dengan adanya materi tentang pelatihan dan pengimplementasian ilmu manajemen ini, diharapkan para siswa memiliki kemampuan lebih setelah lulus nanti. Ilmu manajemen ini juga melatih para siswa untuk lebih mandiri dalam menentukan keputusan untuk melanjutkan kependidikan tinggi atau bekerja atau malah berwirausaha.

\subsection{Rumusan Masalah}

Berdasarkan latar belakang masalah yang sudah dipaparkan diatas bahwa dibutuhkan pelatihan dan pengimplementasian ilmu mananjemen pada dunia kerja serta dunia industri, oleh karena itu kami merumuskan masalah dalam pengabdian kepada masyarakat ini yaitu : Bagaimana inovasi dan kreatifitas masyarakat dalam menghadapi pandemic Covid-19 pada masa new normal serta bagaimana kiat pemasaran produk inovasi yang diciptakan para ibu atau wali murid peserta didik Rumah Pintar Tangerang Raya?

1.3 Tujuan Pengabdian kepada Masyarakat Untuk meningkatkan keterampilan serta kemampuan berinovasi dalam mempertahankan perekonomian dalam Rumah Tangga pada masa new normal Covid-19 pada para ibu atau wali murid peserta didik Rumah Pintar Tangerang Raya?

1.4 Manfaat Masyarakat

Pengabdian kepada

a. Secara Teoritis

Pengabdian ini diharapkan dapatkan memberikan sumbangan dalam aspek teoritis (keilmuan) yaitu dapat memberikan pemikiran, pengetahuan dan gambaran yang lebih jelas mengenai faktor-faktor fundamental dan sebagai aplikasi penerapan dalam ilmu manajemen.

b. Secara Praktis

Hasil pengabdian ini diharapkan dapat memberikan gambaran secara nyata bagi para ibu atau wali murid peserta didik Rumah Pintar Tangerang Raya dalam mengasah keterampilan guna memperoleh penghasilan tambahan dalam menghadapi pandemic Covid19.

\section{TINJAUAN PUSTAKA}

\subsection{Definisi Pelatihan}

Menurut Chris Rowley, pelatihan 
adalah cara untuk memperoleh pengetahuan dan keahlian-keahlian sebagai sebuah hasil dari pembelajaran mengenai kejuruan atau keahliankeahlian praktis dan pengetahuan yang berhubungan kepada kompetensikompetensi spesifik yang berguna.

Menurut Jusmaliani, pelatihan adalah proses melatih karyawan baru atau karyawan yang akan memperoleh penempatan baru dengan keterampilan dasar yang akan memperoleh penempatan baru dan keterampilan dasar yang diperlukannya untuk melaksanakan pekerjaan.

\subsection{Definisi Masker}

Masker menurut (Cohen \& Birdner, 2012) adalah perlindungan pernafasan yang digunakan sebagai metode untuk melindungi individu dari menghirup zatzat berbahaya atau kontaminan yang berada diudara, perlindungan pernafasan atau masker tidak dimaksudkan untuk menggantikan metode pilihan yang dapat menghilangkan penyakit, tetapi digunakan untuk melindungi secara memadai.

Sedangkan masker Non Medis itu sendiri adalah masker yang terbuat dari lapisan kain tertentu yang dibuat untuk menggantikan masker medis yang menagalami kelangkaan dimasa Pandemi Covid-19 ini. Disebut dengan non medis karena produk tersebut belum melewati uji/ standarisasi kelayakan. Prinsipnya masker non medis ini diproduksi untuk dapat menahan droplet dan tidak untukairborne.

\subsection{Definisi ManajemenPemasaran}

Menurut Kotler \& Keller, manajemen pemasaran diartikan sebagai seni dan ilmu memilih pasar sasaran dan meraih, mempertahankan, serta menumbuhkan pelanggan dengan menciptakan, menghantarkan dan mengkomunikasikan nilai pelanggan yang unggul. Menurutnya juga manajemen pemasaran adalah suatu proses yang dilakukan untuk menganalisis, merencanakan, mengkordinasikan program-program yang menguntungkan perusahaan, dan juga dapat diartikan sebagai ilmu memilih pangsa pasar supaya dapat menciptakan nilai yang unggul.

Menurut Buchari Alma, manajemen pemasraan adalah merencanakan, pengarahan, serta pengawasan seluruh kegiatan pemasaran dalam perusahaan ataupun bagian pemasaran.

Menurut John W Mullins, manajemen pemasaran adalah proses menganalisis, memerapkan, mengkoordinasikan dan mengendalikan program, yang melibatkan konsepsi, penetapan harga, promosi, dan distribusi produk, jasa dan ide-ide yang dirancang untuk menciptakan dan memelihara pertukaran yang menguntungkan dengan target pasar untuk tujuan mencapai tujuan organisasi.

Menurut Peter R Dickon, manajemen pemasaran adalah kegiatan organisasi yang terlibat dalam memahami apa yang konsumen inginkan dan bagaimana merekaberperilaku.

Menurut Winardi, manajemen Pemasaran ialah proses pengambilan suatu keputusan, perencanaan, pengawasan aspek-aspek pemasraan sesuatu perusahaan sehubungan dengan konsep pemasaran, didalam system pemasaran.

\subsection{Definisi New Normal}

New normal adalah langkah percepatan penanganan Covid-19 dalam bidang kesehatan, sosial, dan ekonomi. Scenario new normal dijalankan denngan mempertimbangkan kesiapan daerah dan hasil riset epidemiologis daerah terkait. Badan Bahasa Indonesia memberi istilah yaitu kenormalan baru.

New normal menurut Pemerintah Indonesia adalah tatanan baru utnuk beradaptasi dengan Covid-19. Masyarakat harus menjaga produktivitas ditengah pandemi virus corona hingga ditemukannya vaksin definitive dengan standar internasional. 
Loyalitas Kreativitas

Aldi Masyarakat Kreatif
P-ISSN 2722-2101, E-ISSN 2722-4201

Program Studi Ekonomi Manajemen Universitas Pamulang

Jurnal LOKABMAS Kreatif Vol.02,No.01,Maret 2021 Hal. 36-47

Email:jurnalkreatif.manajemen@gmail.com

\subsection{Definisi Covid 19}

Covid-19 singkatan dari Corona Virus Disease 2019, menurut WHO Corona virus merupakan keluarga besar virus yang menyebabkan penyakit pada manusia dan hewan. Pada manusia biasanya menyebabkan penyakit infeksi saluran pernafasan, mulai flu biasa hingga penyakit yang serius seperti Middle East Respiratory Syndrome (MERS) dan Sindrom Pernafasan Akut Berat / Severe Acute Respiratory Sundrome (SARS). Corona virus jenis baru yang ditemukan pada manusia sejak kejadian luar biasa muncul di Wuhan China, Pada Desember 2019, kemudian diberi nama Severe Acute Respiratory Syndrome Coronavirus 2 (SARS-COV2) dan menyebabkan penyakit Coronavirus Disease-2019 (Covid- 19).

Gejala Covid-19 secara umum diawali dengan demam $>380 \mathrm{C}$, batuk kering dan sesak nafas, jika ada orang yang dalam 14 hari sebelum muncul gejala tersebut pernah melakukan perjalanan ke Negara terjangkit atrau pernah merawat/kontak erat dengan penderita Covid-19, maka terhadap orang tersebut akan dilakukan pemeriksaan laboratorium lebih lanjut untuk memastikan diagnosisnya. Orang yang memiliki gejala Covid-19 sekitar $80 \%$ dapat pulih tanpa perlu perawatan khusus. Sekitar 1 dari setiap 6 orang mungkin akan mendeerita sakit yang parah, seperti disertai pneumia atau kesulitan bernafas, yang biasanya muncul secarabertahap.

Menurut WHO virus corona menyebar orang ke orang melalui tetesan kecil dari hidung atau mulut yang menyebar ketika sesorang batuk atau menghembuskan nafas. Tetesan kecil ini kemudian jatuh ke benda yang disentuh oleh orang lain, orang tersebut kemudian menyentuh mata, hidung atau mulut. Berdasarkan studi yang ada saat ini belum ditemukan penyebaran Covid-19 melalui udara bebas.

\section{MATERI DAN METODE \\ PELAKSANAAN}

\subsection{Kerangka Pemecahan Masalah}

Persetujuan proposal pengabdian kepada masyarakat pada kampus Universitas Pamulang dan Rumah Pintar Tangerang Raya yang beralamat di Komplek Griya Asri Pamulang Blok E9 N0.7, Kelurahan Bakti Jaya, Kecamatan Setu, Kota Tangerang Selatan. Guna membekali para ibu atau wali murid peserta didik Rumah Pintar Tangerang Raya dalam mengasah keterampilan guna memperoleh penghasilan tambahan dalam menghadapi pandemic Covid- 19.

Kegiatan ini meliputi bagaimana penerapan ilmu manajemen dalam strategi pemasaran masker manual dan para ibu atau wali murid peserta didik Rumah Pintar Tangerang Raya menjadi terbuka pemikirannya dalam mengatur kehidupan financial mereka secara mandiri dan bermanfaat untuk orang lain.

Persiapan yang dilakukan adalah segala hal yang terkait dengan materi, bahan dan alat sesuai dengan tema secara baik. Hasil persiapan tersebut dimaksudkan agar materi tersampaikan dengan mudah dan dimengerti serta dipahami oleh para ibu atau wali murid peserta didik Rumah Pintar Tangerang Raya. Realisasi Pemecahan Masalah

Kegiatan pengabdian dilaksanakan dengan realisasi rincian acara pelaksanaan sebagai berikut :

Tabel 3.1

Acara Pelaksanaan Kegiatan

Sabtu, 21 November 2020

\begin{tabular}{|c|c|c|}
\hline $\begin{array}{l}\text { WAK } \\
\text { TU }\end{array}$ & $\begin{array}{l}\text { URAIAN } \\
\text { KEGIATA } \\
\mathbf{N}\end{array}$ & $\begin{array}{l}\text { KETERAN } \\
\text { GAN }\end{array}$ \\
\hline $\begin{array}{l}13.00- \\
13.30 \\
\end{array}$ & $\begin{array}{l}\text { Registrasi } \\
\text { Peserta }\end{array}$ & Panitia \\
\hline $\begin{array}{l}13.30 \\
- \\
13.40\end{array}$ & $\begin{array}{l}\text { Pembukaaa } \\
\text { n Acara }\end{array}$ & $\begin{array}{l}\text { Mc : Agus } \\
\text { Herianto }\end{array}$ \\
\hline $\begin{array}{l}13.40 \\
- \\
14.00\end{array}$ & $\begin{array}{l}\text { Pembacaan } \\
\text { Ayat- ayat } \\
\text { suci } \\
\text { Quran }\end{array}$ & $\begin{array}{l}\text { Alisya } \\
\text { Asyaroh }\end{array}$ \\
\hline
\end{tabular}


Loyalitas Kreativitas

Aldi Masyarakat Kreatif
P-ISSN 2722-2101, E-ISSN 2722-4201

Program Studi Ekonomi Manajemen Universitas Pamulang Jurnal LOKABMAS Kreatif Vol.02,No.01,Maret 2021 Hal. 36-47

Email:jurnalkreatif.manajemen@gmail.com

\begin{tabular}{|c|c|c|}
\hline $\begin{array}{l}14.00 \\
- \\
14.30\end{array}$ & $\begin{array}{l}\text { Sambutan } \\
\text { Ketua } \\
\text { Rumah } \\
\text { Pintar } \\
\text { Tangerang } \\
\text { Raya }\end{array}$ & $\begin{array}{l}\text { Irsyad } \\
\text { Maulana, S.E }\end{array}$ \\
\hline $\begin{array}{l}14.30 \\
- \\
15.00 \\
\end{array}$ & $\begin{array}{l}\text { Sambutan } \\
\text { Ketua } \\
\text { Pelaksana } \\
\end{array}$ & $\begin{array}{l}\text { Indri } \\
\text { Kharisma, } \\
\text { S.E.,M.M. }\end{array}$ \\
\hline $\begin{array}{l}15.00 \\
- \\
16.00\end{array}$ & $\begin{array}{l}\text { Pemilihan } \\
\text { bahan yang } \\
\text { tepat untuk } \\
\text { masker non- } \\
\text { medis serta } \\
\text { pemaparan } \\
\text { tentang } \\
\text { pentingnya } \\
\text { penggunaan } \\
\text { masker } \\
\text { dimasa } \\
\text { pandemicC } \\
\text { ovid-19 }\end{array}$ & $\begin{array}{l}\text { Ananda } \\
\text { Hadistia, } \\
\text { S.E.,M.M. }\end{array}$ \\
\hline $\begin{array}{l}16.00 \\
- \\
16.30\end{array}$ & Istirahat & Panitia \\
\hline $\begin{array}{l}16.30 \\
- \\
17.00\end{array}$ & Selesai & Panitia \\
\hline
\end{tabular}

Minggu, 22 November 2019

\begin{tabular}{|c|c|c|}
\hline $\begin{array}{l}\text { WAK } \\
\text { TU }\end{array}$ & $\begin{array}{l}\text { URAIAN } \\
\text { KEGIATAN }\end{array}$ & $\begin{array}{l}\text { KETERA } \\
\text { NGAN }\end{array}$ \\
\hline $\begin{array}{l}13.00 \\
- \\
13.15\end{array}$ & Pembukaan & $\begin{array}{l}\text { Mc : Agus } \\
\text { Herianto }\end{array}$ \\
\hline $\begin{array}{l}13.15 \\
- \\
13.45\end{array}$ & $\begin{array}{l}\text { Pengarahan } \\
\text { ketua } \\
\text { pelaksana }\end{array}$ & $\begin{array}{l}\text { Indri } \\
\text { Kharisma, } \\
\text { S.E.,M.M. }\end{array}$ \\
\hline $\begin{array}{l}13.45 \\
- \\
14.30\end{array}$ & $\begin{array}{l}\text { Materi I : } \\
\text { Peranan dan } \\
\text { Pengimpleme } \\
\text { ntasian } \\
\text { masker dalam } \\
\text { kehidupan } \\
\text { sehari-hari }\end{array}$ & $\begin{array}{l}\text { Ardi } \\
\text { Bachtiar, } \\
\text { S.E., M.M. }\end{array}$ \\
\hline $\begin{array}{l}14.30 \\
- \\
15.00\end{array}$ & $\begin{array}{l}\text { Materi II : } \\
\text { Pemaparan } \\
\text { materi } \\
\text { tentang }\end{array}$ & $\begin{array}{l}\text { Shela Indah } \\
\text { Savitri, } \\
\text { S.Kom., } \\
\text { M.M. }\end{array}$ \\
\hline
\end{tabular}

\begin{tabular}{|c|c|c|}
\hline & $\begin{array}{l}\text { sosialisasi } \\
\text { manajemen } \\
\text { pemasaran } \\
\text { dengan } \\
\text { memanfaatka } \\
\text { n teknologi } \\
\text { digital. }\end{array}$ & \\
\hline $\begin{array}{l}15.00 \\
- \\
15.20\end{array}$ & $\begin{array}{ll}\text { Sesi } & \text { tanya } \\
\text { jawab } & \end{array}$ & Panitia \\
\hline $\begin{array}{l}15.20 \\
- \\
15.30\end{array}$ & Break & $\begin{array}{l}\text { Seluruh } \\
\text { Peserta }\end{array}$ \\
\hline $\begin{array}{l}15.30 \\
- \\
15.40 \\
\end{array}$ & $\begin{array}{l}\text { Kesan dan } \\
\text { Pesan peserta }\end{array}$ & $\begin{array}{l}\text { Indra Januar } \\
\text { Rukmana, } \\
\text { S.E.,M.M. }\end{array}$ \\
\hline $\begin{array}{l}15.40 \\
- \\
15.50\end{array}$ & $\begin{array}{l}\text { Penyerahan } \\
\text { souvenir } \\
\text { kepada SMK } \\
\text { Lingga } \\
\text { Kencana } \\
\text { Depok }\end{array}$ & Panitia \\
\hline $\begin{array}{l}15.50 \\
- \\
16.00\end{array}$ & $\begin{array}{l}\text { Penyerahan } \\
\text { souvenir } \\
\text { kepada siswa } \\
\text { siswi SMK } \\
\text { Lingga } \\
\text { Kencana } \\
\text { Depok }\end{array}$ & Panitia \\
\hline $\begin{array}{l}16.00 \\
- \\
16.30\end{array}$ & Foto bersama & $\begin{array}{l}\text { Panitia dan } \\
\text { Peserta }\end{array}$ \\
\hline $\begin{array}{l}16.30 \\
- \\
16.40\end{array}$ & $\begin{array}{l}\text { Kultum dan } \\
\text { Doa penutup }\end{array}$ & $\begin{array}{l}\text { Indra Januar } \\
\text { Rukmana, } \\
\text { S.E.,M.M. }\end{array}$ \\
\hline
\end{tabular}

\subsection{Khalayak Sasaran}

Sasaran Pengabdian kepada Masyarakat kali ini yaitu para ibu atau wali murid peserta didik Rumah Pintar Tangerang Raya, terdiri dari 10 orang wali murid peserta didik.

\subsection{Tempat dan Waktu Pengabdian}

a. Tempat Pengabdian

Pelaksanaan kegiatan pengabdian kepada masyarakat di Komplek Griya Asri Pamulang Blok E9 N0.7, Kelurahan Bakti Jaya, Kecamatan Setu, Kota Tangerang Selatan. 
Loyalitas Kreativitas
Aldi Masyarakat Kreatif
P-ISSN 2722-2101, E-ISSN 2722-4201

Program Studi Ekonomi Manajemen Universitas Pamulang

Jurnal LOKABMAS Kreatif Vol.02,No.01,Maret 2021 Hal. 36-47

Email:jurnalkreatif.manajemen@gmail.com b. Waktu Pengabdian

Pengabdian kepada Masyarakat dilaksanakan pada Hari Sabtu dan Minggu tanggal 21-22 November 2020, dilaksanakan dari pukul 13.0017.00 .

\subsection{Metode Kegiatan}

Metode kegiatan yang digunakan adalah dengan cara survey dan kami mengunjungi Rumah Pintar di Komplek Griya Asri Pamulang Blok E9 N0.7, Kelurahan Bakti Jaya, Kecamatan Setu, Kota Tangerang Selatan, dan memberikan pelatihan disana.

\section{HASIL DAN PEMBAHASAN \\ 4.1Gambaran Umum}

Tempat pelaksanaan kegiatan pengabdian masyarakat oleh dosen-dosen dari Universitas Pamulang adalah rumah pintar dengan nama Rumah Pintar Tangerang Raya yang beralamatkan di Jl. Komplek Griya Asri Pamulang Blok E9 N0.7, Kelurahan Bakti Jaya, Kecamatan Setu, Kota Tangerang Selatan. Para pemateri menjelaskan dan memberikan gambaran secara singkat bagaimana membuat masker non medis manual dan ilmu manajemen pemasaran diterapkan secara langsung di dalam kehidupan sehari-hari.

\section{2 \\ Pembahasan}

Hasil

dan

Berikut materi dalam pelatihan pembuatan masker non medis secara manual serta sosialisasi manajemen pemasaran di Era New Normal, yang diberikan kepada para ibu atau wali murid di Rumah Pintar Tangerang Raya.

a. SesiI

Narasumber : Ananda Hadistia, S.E., M.M. Kegiatan : Pemaparan materi dan curahpendapat

Tema : Pemilihan bahan yang tepat untuk masker non-medis serta pemaparan tentang pentingnya penggunaan masker dimasa pandemicCovid-19.

Sebelum memulai untuk praktek pembuatan masker non medis, ada baiknya kita mengetahui bahan apa saja yang tepat dan cocok untuk digunakan dalam pembuatan masker non medis tersebut. Berikut beberapa diantaranya jenis bahan yang tepat untuk pembuatan masker non medis:

1) Katun(Kapas)

Bahan yang paling popular untuk masker non medis adalah katun, terutama yang diperjual belikan secara online, dan menurut Dr. Gustavo Ferrer, ahli paru dan Presiden Jaringan Kesehatan Ahli Perawatan Intensif, bahan katun adalah salah satu bahan terbaik untuk tujuan pencegahan virus corona. Hal ini karena katun memiliki serat kecil yang dapat menahan partikel virus, sehingga virus tidak dapat menembus kain dan terhirup oleh penggunaannya.

Penelitian awal yng dilakukan oleh produsen alat pembersih udara. Smart Air, yang menggunakan kipas dan penghitung partikelpartikel laser, membuktikan keefektivitasan masker dari bahan katun ini. Dari penelitian tersebut, ditemukan bahwa tiga bahan paling baik (berdasarkan keseimbangan perlindungan dan kemudahan bernafas) terbuat dari kapas (katun). Secara spesifik, bahan pertama adalah denim dan seprai dengan jumlah benang 120 dan dapat menyaring 90 persen partikel besar 24-29 persen partikel kecil.

Bahan kedua adalah kanvas dengan ketebalan 0,4-0,5 milimeter, dapat menyaring 84 persen partikel besar dan 19 persen partikel kecil. Sedangkan bahan ketiga adalah bahan katun dari kaos dan bandana menyaring kurang dari 10 persen paertikel kecil.

2) Nilon

Berdasarkan penelitian Smart Air, bahan nilon 70D juga efektif dalam penyaringan yang dapat menahan $77 \%$ partikel besar dan 12 partikel kecil, dan juga memungkinkan pengguna untuk dapat bernafas dengan mudah. Para peneliti juga menguji bahan nilon 40D yang bahkan memiliki tiungkat filtrasi yang lebih tinggi, tetapi lemah dalam keleluasaan bernafas sama seperti bahan kanvas.

\section{3) BahanKertas}

Penelitian Smart Air memenumkan bahwa tisu kertas dan tisu di took- toko (yang sering digunakan untuk membersihkan minyak) dapat memberikan perlindungan baik dan keleluasaan bernafas. Sedangkan filter kopi juga efektif untuk menyaring, tetapi tidak memungkinkan pengguna bernafas dengan nyaman. 
Loyalitas Kreativitas

Aldi Masyarakat Kreatif
P-ISSN 2722-2101, E-ISSN 2722-4201

Program Studi Ekonomi Manajemen Universitas Pamulang

Jurnal LOKABMAS Kreatif Vol.02,No.01,Maret 2021 Hal. 36-47

Email:jurnalkreatif.manajemen@gmail.com

\section{4) SeratAlami}

Secara keseluruhan, Smart Air lebih merekomendasikan serat alami dibandingkan sintetis, mkarena bahan alami, seperti kertas dan katun, memiliki kekasaran dan ketidakteraturan bahan yang dapan meningkatkan kemampuan penyaringan mereka.

5) Kombinasi Katun dengan SutraAlami Para peneliti juga melaporkan bahwa kombinasi katun dengan sutra alami atau sifon dapat secara efektif menyaring partikel aerosol bila ukuran pas. Sebuah lapisan kain katun yang diikat rapat dan dikombinasikan dengan dua lapisan sifon polyester dan spandex, kain tipis yang sering digunakan dalam gaun malam, dapat menyaring partikel aerosol paling banyak (sekitar 80-99\% tergantung pada ukuran partikel). Kemampuan tersebut hamper mendekati efektiviats dari masker N95. Mengganti sifon dengan sutra alam atau kain flannel atau hanya menggunakan selimut katun dengan batting kapas- poliester juga menghasilkan hasil yang serupa. Setelah mengetahui bahan apa yang sesuai untuk pembuatan masker non medis sekarang kita bahas tentang pentingnya penggunaan masker non medis di masa pandemic Covid-19 ini. Maskersangatpentingdigunaakansaatpandemic ini,sampai-sampai

Pemerintah memberikan peraturan baru bahwa setiap Warga Negara Indonesia wajib menggunakan masker saat berpergian kemanapun dan kapan pun, jika ada yang melanggar setiap Warga Negara Indonesia berhak mendapatkan sanksi sesuai yang telah ditetapkan sesuai kebijakan pemerintah Kota maupun daerahnya masing-masing, baik itu sanksi social ataupun sanksimaterial.

Mengapa penggunaan masker sangat penting, seperti apa yang sudah dibahas sebelumnya, bahwapenularan virus corona dapat melalui percikan kecil yang dikelaurkan pada saat bicara ataupun batuk (droplet), oleh karena itu penggunaan masker bertujuan untuk menahan partikel kecil (droplet) yang keluar melalui mulut saat berbicara atau batuk tersebut agar tidak masuk kehidung atau mulut lawan biacara kita ataupun sebaliknya. Karena kita tidak mengetahui bahwa lawan bicara kita atau kita sendiri sedang menjadi pembawa virus atau tidak.

b. SesiII

Narasumber : Ardi Bachtiar, S.E.,M.M.

Kegiatan : Praktek pembuatan masker nonmedis

1) Persiapan Bahan dan

CaraPembuatan Bahan yang digunakan:

1. Bahan KatunJepang

2. Bahan Katun LapisanDalam

3. Karet (untuk tali masker)

$4 . \quad$ Benang

5. JarumJahit

$6 . \quad$ JarumPentul

$7 . \quad$ Peniti

8. Kertas Pola danSpidol

Langkah pertama Menyiapkan Kain :

Sebaiknya gunakan kain yang memang biasa dipakai untuk membuat masker bila tidak memilikinya, bisa menggunakan kain jenis apapun akan tetapi harus tetap dilapisi 2 atau 3 lapis kain, hal ini karena lebih banyak lapisan maka lebih banyak filter yang digunakan akan jauh lebih baik. Jangan lupa bagian dalam kainnya harus lebih tebal disbanding lapisan luar. Selain itu juga siapkan karet untuk digunakan sebagai talimasker.

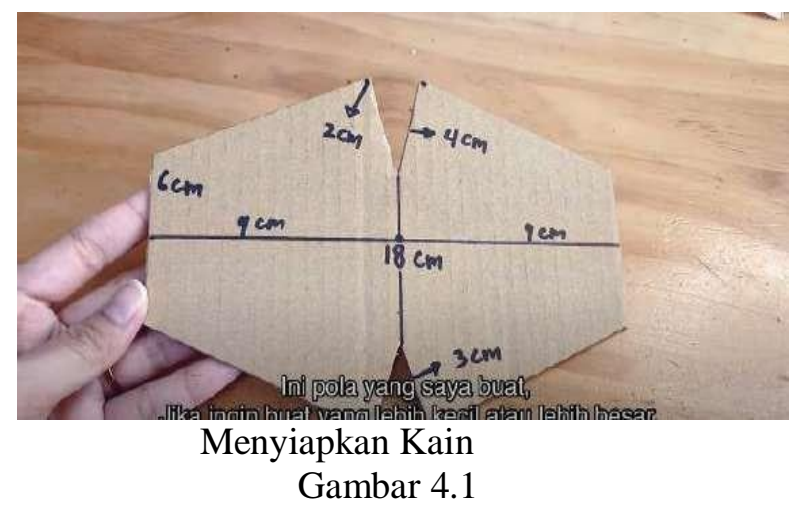

Sumber : Merdeka.com LangkahKedua

Membuat Pola:

Membuat pola sangat lah penting untuk mrmudahkan dalam mencetak ukuran pada kain, bisa juga menggunakan kardus bekas dirumah untuk membuat pola pada masker. Pola dibuat sesuai selera. Umumnya diseuaikan dengan ukuran wajah orang Indonesia pada umumnya, yang paling penting masker yang 
Loyalitas Kreativitas

Aldi Masyarakat Kreatif
P-ISSN 2722-2101, E-ISSN 2722-4201

Program Studi Ekonomi Manajemen Universitas Pamulang

Jurnal LOKABMAS Kreatif Vol.02,No.01,Maret 2021 Hal. 36-47

Email:jurnalkreatif.manajemen@gmail.com dibuat nantinya sesuai dan cocok dengan bentukwajah.

\section{Membuat Pola \\ Gambar 4.2}

Sumber : Merdeka.com Langkah Ketiga

Potong Kain Sesuai Pola :

Cara membuat masker tanpa mesin jahit selanjutnya yakni memotong kain dengan pola yang dibuat sebelumnya. Perlu diperhatikan, jangan memotong pas dengan bentuk pola. Usahakan memberi jarak sedikit disemua sisinya. Kalian bisa memberikan jarak 0,5 cm$0,8 \mathrm{~cm}$. semua kain juga harus dipotong sesuai bentuk pola.

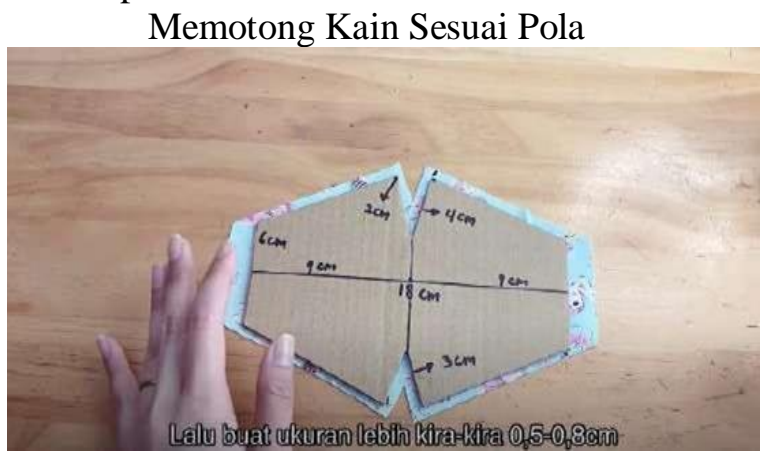

Gambar 4.3

Sumber : Merdeka.com Langkah Keempat Jahit Masker :

Langkah selanjutnya yaitu lipat kain menjadi dua. Kemudian,jahit

bagian yang berbentuk" $\mathrm{V}$ " tanpa menggunakan mesin jahit.Tidak masalah menggunakan tekhnik menjahit seperti apa, yang terpenting jahtannya bisa rapat dan kuat. Kemudian tumpuk kain yang telah disiapkan sebelumnya. Jangan lupa beri jarum pentul agar tidak bergeser.

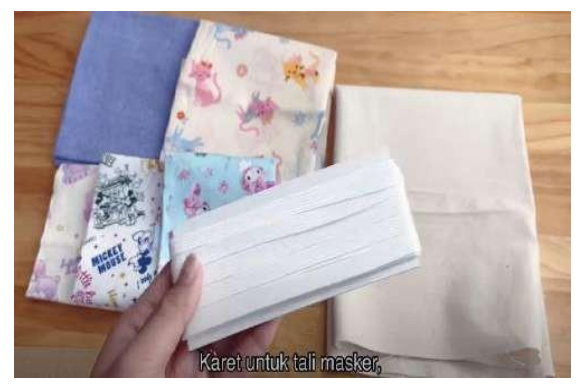

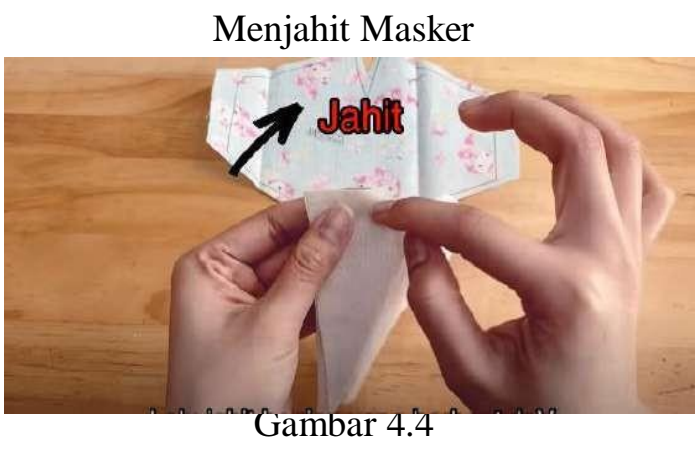

Sumber : Merdeka.com

Selanjutnya, jahit sisi bagian lainnya pada masker. Namun, sisakan bagian masker untuk tidak dijahit terlebihdahulu.

Menyisakan BagianMasker

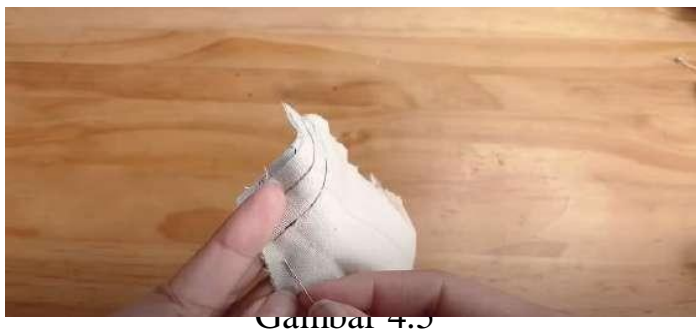

Sumber : Merdeka.com

Langkah kelima Membalik Kain :

Saat menjahit kain harus dibalik dahulu. Setelah selesai, balik kain bagian dalam hingga keluar semuanya. Lipat kedalam bagian ujung kain yang belum dijahit. Lalu, jahit masker dengan teknik yang sama.

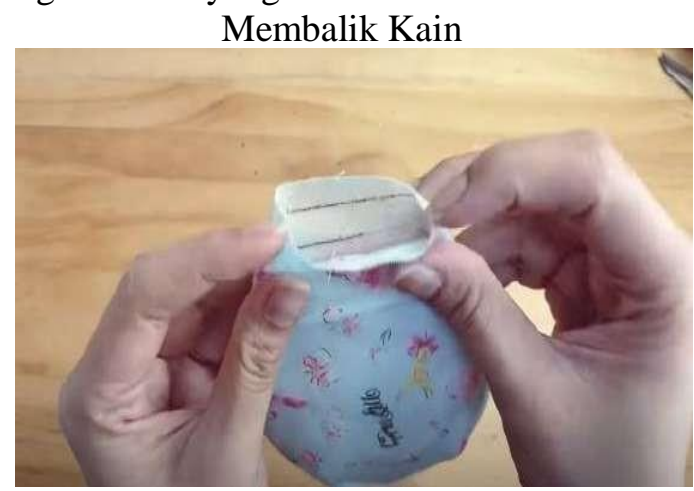

Gambar4.6

Sumber : Merdeka.com Langkah Terakhir Pasang Tali Pada Masker :

Kemudian, lipat ujung masker sedikit kebagian dalam. Nantinya, disitulah tapi masker akan diletakkan. Jahit ujung masker tersebut namun 
Loyalitas Kreativitas
Aldi Masyarakat Kreatif
P-ISSN 2722-2101, E-ISSN 2722-4201

Program Studi Ekonomi Manajemen Universitas Pamulang

Jurnal LOKABMAS Kreatif Vol.02,No.01,Maret 2021 Hal. 36-47

Email:jurnalkreatif.manajemen@gmail.com tetap sisakan dua lubang diujungnya. Potong tali masker sesuai selera. Kaitkan peniti keujung tali. Masukkan kedalam lipatan kain masker yang telah disiapkan sebelumnya. Ikat ujung tali masker.

c. Sesi II

Narasumber: Shela Indah Savitri, S.Kom.,M.M.

Kegiatan : Pemaparan materi, curah pendapat dandiskusi

Tema : Pemaparan materi tentang sosialisasi manajemen pemasaran dengan memanfaatkan teknologi digital.

Tujuan utama dari kegaiatan pengabdian masyarakat ini tentu saja untuk membantu para ibuatau wali murid peserta didik di Rumah Pintar

Tangerang Raya (RPTR) ini untuk memiliki peluang usaha tambahan ditengah pandemic Covid-19 ini, dalam pemasarannya diharapkan para ibu atau wali murid ini diharapkan dapat memanfaatkan teknologi digital yang ada saat ini. Maka pemateri akan menyampaikan 7 strategi bisnis untuk bersaing di Era Digital, yaitu sebagai berikut:

1) Memanfaatkan teknologi

Setiap ibu atau wali murid peserta didik di RPTR ini diharapkan 'melek' teknologi, karena dunia digital dan teknologi sekarang ini tidak dapat dipisahkan keberadaannya. Apalagi zaman modern saat ini, mau tidak mau, suka tidak suka teknologi harus digunakan. Terlebih lagi jika competitor sudah lebih dulu menggunakannya. Sejatinya teknologi dibuat untuk membantu dan mempermudah pekerjaan manusia, contohnya kegiatan pemasaran dapat dilakukan dengan memanfaatkan internet atau juga dalam pembukuan dalam bisnis dengan menggunakancomputer.

2) Menggunakan Social Media

Indonesia memiliki banyak pengguna social media seperti Twitter, Instagram, Facebook, Youtubedan sebagainya. Karena itu media social dapat dijadikan alat dalam strategi bisnis. Media social dapat diterapkan langsung melalui strategi pemasaran. Selain murah, cara penggunaannya pun mudah, tidak perlu memiliki keahlian khusus cukup dengan memasarkan produk atau jasa saja, juga dapat memanfaatkan fitu-fitur yang disediakan untuk membuat konten yang menarik.

3) Menggunakan Digital Marketing Sekain social media, para ibu atau wali murid peserta didik RPTR juga diharapkan dapat menerapkan digital marketing. Digital marketing adalah aktivitas promosi sebuah brand atau pun produk/jasa menggunakan media elektronik atau digital. Jika tidak dapat menggunakan digital marketing bisa juga menggunakan jasa $e$-commerce yang menjual jasa digital agency yang dpaat membantu mengembangkan bisnis. Adapun teknik pemasaran dalam diginat marketing seperti Search engine optimazion (SEO), billboard elektronik, iklan televisi dan radio, email marketing dan lainnya.

4) Mobile Friendly

Tingginya jumlah pengguna smartphone dan produk gadget lainnya, juga peru diperhatikan dan perlu penyesuaian dalam strategi pemasarandengan tampilan mobile friendly. Sehingga akan banyak orang yang melihat toko onlie yang para ibu buat, sehingga dapat menjaring pengunjung lebih banyak.

5) MenggunakanAplikasi

Selain aplikasi media social, saat ini juga banyak aplikasi yang tersedia untuk membatu dalam pekerjaan, misalnya aplikasi akuntansi, aplikasi e-commerce, apliaksi administrasi dll. Aplikasi E- commerce bisa membantu dalam penjualan poduk dengan mudal melalui mobile, apalagi saat ini e-commerce banyak sekali bermunculan, seperti Shopee, Lazada, Tokopedia dansebagainya.

6) Inovasi

Inovasi juga merupakan bagian penting dalam strategi bisnis untuk lebih maju, karena dunia bisnis cepat sekali berubah hamper setiap harinya ada trend baru sehingga inovasi sangat diperlukan untukdapat bersaing dengan competitor.

7) Memberikan pelayananterbaik

Tidak ada yang lebih penting dan berharga dalam dunia bisnis selain memberikan pelayanan terbaik kepada konsumen, dalam media digital pelayanan tersebut contohnya, memberikan informasi sesuai terhadap barang yang dijual, mengirimkan barang sesuai dengan 


\section{Loyalitas Kreativitas \\ Aldi Masyarakat Kreatif}

P-ISSN 2722-2101, E-ISSN 2722-4201

Program Studi Ekonomi Manajemen Universitas Pamulang Jurnal LOKABMAS Kreatif Vol.02,No.01,Maret 2021 Hal. 36-47

Email:jurnalkreatif.manajemen@gmail.com waktu yang telah dijanjikan, dapat memberikan informasi update mengenai

barang yang dikirimkan kepada konsumen, sehingga konsumen dapat memantau paketnya. Mungkin terlihat spele namun pelayanan terbaik akan memberikan dampak yang besar bagi kemajuan toko online anda.

\section{KESIMPULAN DAN SARAN}

Pelaksanaan kegiatan pengabdian kepada masyarakat oleh Lembaga Penelitian dan Pengabdian Masyarakat (LPPM) Universitas Pamulang yang dilakukan oleh dosen-dosen program studi manajemen telah berjalan dengan lancar dan mendapat sambutan hangat dari tempat pelaksanaan kegiatan ini yaitu Rumah Pintar di Komplek Griya Asri Pamulang Blok E9 N0.7, Kelurahan Bakti Jaya, Kecamatan Setu, Kota Tangerang Selatan.

Harapan kami dengan pengabdian ini dapat menambah pemahaman dan wawasan tentang ilmu manajemen dalam DarikegiatanpengabdiankepadaMasyarakatinid apatdisimpulkanbahwa: Pengetahuan dan keterampilan para ibu atau wali murid peserta didik Rumah Pintar Tangerang Raya menjadibertambah. Keterampilan para ibu atau wali murid peserta didik di Rumah Pintar Tangerang Raya dalam memanfaatkan teknologi digital semakin meningkat.

Dalam laporan kegiatan ini mungkin banyak kekurangan yang ada, untuk itu kami berharap masukan dan kritikan dalam rangka perbaikan untuk kegiatan-kegiatan pengabdian masyarakat di masa yang akan datang. Semoga kegiatan pengabdian masyarakat ini dapat bermanfaat bagi masyarakat sekitar Universitas Pamulang.

Akhirnya, kami mengucapkan terima kasih kepada seluruh pihak yang telah mendukung kegiatan yang kami laksanakan dan kami mohon maaf apabila dalam laporan ini banyak ditemukan kekurangan.

\section{DAFTAR PUSTAKA}

Alifa, Syadza, M. Kesos, Bandung; Masalah Ekonomi yang terjadi ditengah masyarakat dimasa pandemic

Covid-19; Diakses dari http://puspensos.kemsos.go.id/mengan alisa-masalah-sosial-ekonomi-

masyarakat-terdampak-covid-19;

diunduh 8 Oktober2020

BBC Indonesia; 30 Maret 2020; Virus Corona: Pendapatan usaha kecil 'pupus' akibat covid-19, pemerintah siapkan bantuan social untuk pekerja harian; Diakses dari http://www.bbc.com/indonesia52059235; Diunduh 04 September 2020.

Ensiklopedia Bebas Wikipedia; 06 November 2020; Pandemi Covid 19; Diakses dari https://id.wikipedia.org/wiki/Pandemi _COVID-19; Diunduh Rabu, 11 November 2020

Fadli, Rizal,dr; 14 Mei 2020 ; Apa Bahan Terbaik untuk Membuat Masker Kain? ; Diakses dari https://www.halodoc.com/artikel/apabahan-terbaik-untuk-membuatmasker-kain; Diunduh, 29 Desember 2020.

Jusmaliani, M.E., Pengelolaan Sumber Daya Insani, Surakarta : Bumi Aksara, 2011, Hal.99.

Mifta, Rizka; 20 April 2020; Definisi Manajemen Menurut Ahli;Diakses dari https://www.brilio.net/serius/17pengertian-manajemen-pemasaranmenurut-para-ahli-jelas-dan-lengkap200420t.html; Diunduh Kamis, 31 Desember 2020.

Mohammadar; Bab II Tinjauan

Pustaka, Definisi Masker; Diakses dari

http://eprints.umm.ac.id/41776/3/jiptu mmpp-gdl-mohammadar-46953-3babii.pdf; Diakses 29 Desember 2020.

Munarsih, M., Savitri, S. I., Putren, I., Wilandari, D. F., \& Abdurohman, D. (2020). Penyuluhan Kesehatan Masyarakat melalui Skill Training Antisipasi COVID-19 dengan Busami (Pembuatan Handsanitizer Alami) Kelompok PKK di Kelurahan Sawah Ciputat. Abdi Laksana: Jurnal Pengabdian Kepada Masyarakat, 1(3), 368-373.

Nuraini, Tanitiya Nimas; Sabtu 11 April 2020; Cara membuat masker kain secara 
Loyalitas Kreativitas

Aldi Masyarakat Kreatif
P-ISSN 2722-2101, E-ISSN 2722-4201

Program Studi Ekonomi Manajemen Universitas Pamulang Jurnal LOKABMAS Kreatif Vol.02,No.01,Maret 2021 Hal. 36-47

Email:jurnalkreatif.manajemen@gmail.com manual; Diakses dari https://www.merdeka.com/trending/ca ra-membuat-masker-tanpa-mesinjahit-mudah-dipraktikkan-

kln.html?page $=8$; diunduh 9 oktober 2020.

Pangestika, Widya; 12 Maret 2019; 7 Strategi Bisnis Untuk Bersaing di Era Digital; Diakses dari https://www.jurnal.id/id/blog/strategibisnis-untuk-bersaing-di-era-digital/; Diunduh Sabtu, 02 Januari 2021.

Putsanra, Dipna Videlia; 29 Mei 2020; Arti New Normal Indonesia: Tatanan Baru Beradaptasi dengan Covid-19; Diakses dari https://tirto.id/arti-new-normalindonesia-tatanan-baru-beradaptasidengan-covid-19-fDB; Diunduh Jumat 01 Januari2021

Rowley, Chris. Manajemen SDM. Jakarta : Rajawali Pers. 2012.

Sastri, Diah; 28 November 2017; Menulis Daftar Pustaka (APA Style); Diakses dari

https://diahsastri.com/2017/11/28/men ulis-daftar-pustaka-apa-style/;

Diunduh Sabtu, 02 Januari 2021.

Suharti, Nita Izky; Agustus 2020.https://bisnismuda.id/rea d/259-nita-izky-suharti/ mengatasipermasalahan-ekonomi-di-saatpandemi-covid-19-yang-anti-panik; diunduh 5 Oktober2020.

Tamtomo, Akbar Bhayu; 16 Mei 2020; Sering disebut - sebut, Apa itu New Normal? Diakses dari https://www.kompas.com/tren/read/20 20/05/16/164600865/sering-disebutsebut-apa-itu-new-normal-?page $=$ all

$$
\text { Diunduh Rabu }
$$$$
30 \text { Desember2020. }
$$

Wahyudi, AMK; 08 Oktober 2020; Pentingnya Menggunakan Masker dimasa Pandemi; Diakses dari https://www.rsuharapanibu.co.id/penti ngnya-menggunakan-masker-dimasapandemi/; Diunduh Jumat, 01 Januari 2021.

Widiyani, Rosmha; 30 Mei 2020; tentang New Normal di Indonesia fakta dan

\begin{abstract}
Kesiapan Daerah; Diakses dari https://news.detik.com/berita/ d-5034719/tentang-new-normal-diindonesia-arti-fakta-dan-kesiapandaerah; diunduh tanggal 23 November 2020 .
\end{abstract}

\section{FOTO KEGIATAN PENGABDIAN KEPADA MASYARAKAT DI RUMAH PINTAR TANGERANG RAYA}

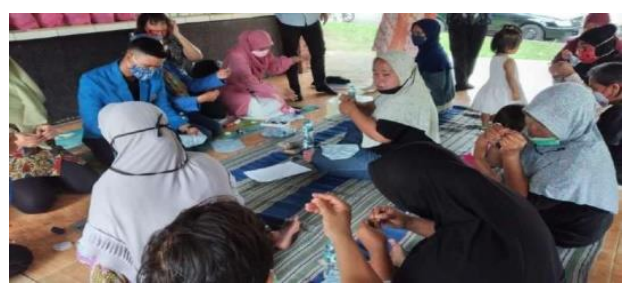

Foto 1. Pembuatan Maskes non medis manual dipimpin oleh Ketua PKM, Ibu Indri Kharisma S.E.,M.M.

Foto 2. Pembagian sembako kepada ibu/wali murid siswa rumah pintar dipimpin oleh Ketua

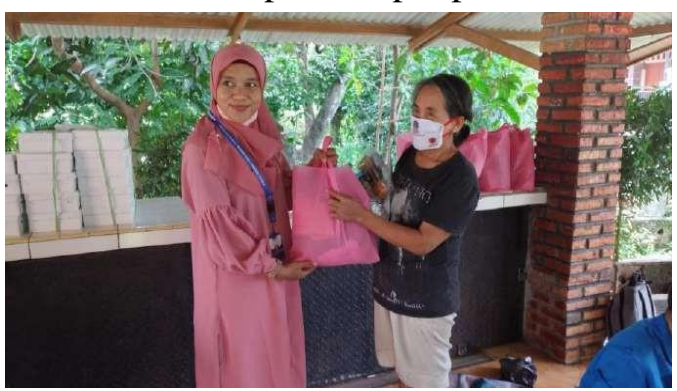

PKM, Ibu Indri Kharisma S.E.,M.M.

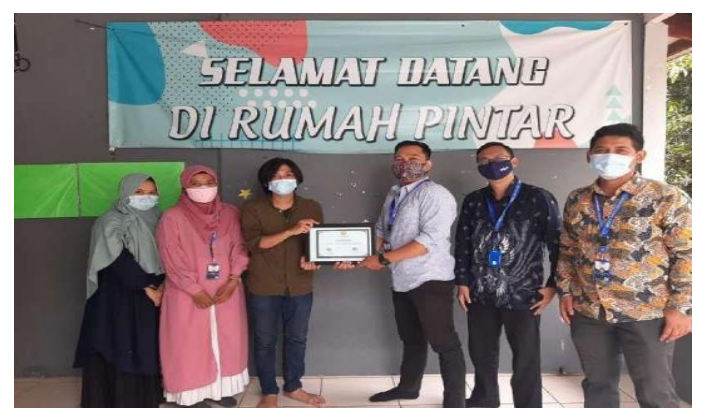

Foto 3. Pennyerahan Piagam kepada Ketua Rumah pintar diwakili oleh Bapak Indra Januar Rukmana, S.E.,M.M. 


\section{Loyalitas Kreativitas \\ P-ISSN 2722-2101, E-ISSN 2722-4201 \\ Aldi Masyarakat Kreatil \\ Program Studi Ekonomi Manajemen Universitas Pamulang \\ Jurnal LOKABMAS Kreatif Vol.02,No.01,Maret 2021 Hal. 36-47 \\ Email:jurnalkreatif.manajemen@gmail.com}

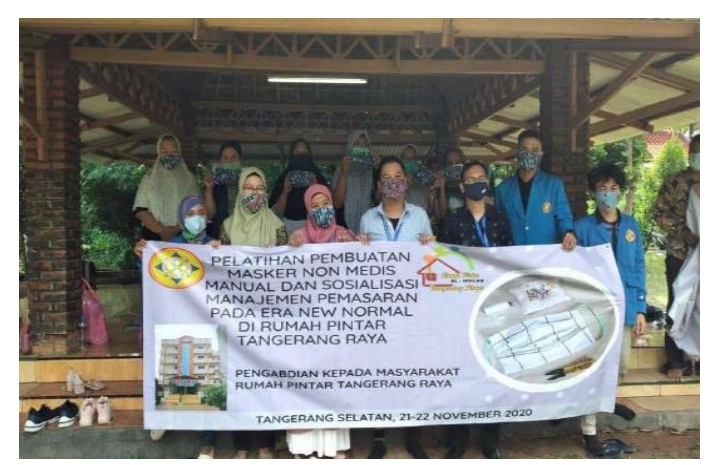

Foto 4. Foto Bersama Dosen dan Mahasiswa setelah kegiatan PKM

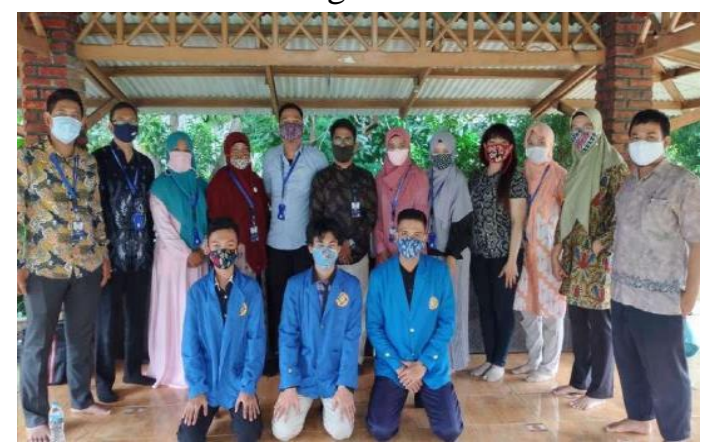

Foto 5. Foto Bersama Dosen dan Mahasiswa setelah kegiatan PKM 